физическая подготовленность оказывает существенное влияние на уровень технического мастерства в баскетболе.

Выводы. Формирования высокого уровня технического мастерства в баскетболе не возможно без эффективного управление физической подготовкой, на различных этапах спортивной подготовки. Ведущие специалисты в сфере спортивной тренировки, такие как Ю.В. Верхошанский, Л.В. Волков, А.А. Шерстюк, Ж.К. Холодов, В.С. Кузнецов, Н.Г. Озолин, Ю.П. Кобяков и Д.Н. Мисиров утверждают: «Общая физическая подготовка достигает своих целей только при условии постоянства и непрерывности. Она входит обязательной составной частью в тренировки на всех периодах подготовки спортсменов, не теряет она своего значения и при достижении высокого мастерства». «... Дополнительное образование детей является актуальным и необходимым звеном системы непрерывного образования, направленным на удовлетворение их индивидуальных потребностей в интеллектуальном, и физическом совершенствовании и организацию их свободного времени».

$$
\text { *** }
$$

1. Бабушкин Е.Г. Физическая культура: учебное пособие в 2 ч. / Е.Г. Бабушкин, В.А. Барановский, М.Ю. Моор. - Омск: ОГИС, 2011. - Ч. 1. -127c.

2. Машинистова Н.В. Нормативно-правовое обеспечение системы дополнительного образования детей в Российской Федерации [Текст] // Педагогика: традиции и инновации: материалы III Междунар. науч. конф. (г. Челябинск, апрель 2013 г.). - Челябинск: Два комсомольца, 2013. - С. 37-40. [Электронный ресурс]: https://moluch.ru/conf/ped/archive/69/3740.

3. Озолин, Н.Г. Настольная книга тренера: наука побеждать / Н.Г. Озолин. - М.: Изд. АСТ, 2003. - 863 с.

4. Платонов, В.Н. Система подготовки спортсменов в олимпийском спорте. Общая теория и её практические приложения. / В.Н. Платонов. - К.: Олимпийская литература, 2004. - 806 с.

5. Холодов, Ж.К. Теория и методика физического воспитания и спорта. / Ж.К. Холодов, В.С. Кузнецов. - М.: Издательский центр «Академия», 2003. - 480 с.

6. Феуерман В.В. Функциональное состояние организма обучающихся общеобразовательного учреждения и средство, обеспечивающее его стабильность. / «Научный диалог: Молодой учёный» Сборник статей по материалам XIX международной научно-практической конференции, 22 сентября 2018 г. / В.В. Феуерман, М.С. Бойко. - Санкт-Петербург, 2018. - С. 18-22

7. Шерстюк, А.А. Баскетбол: основные технические приемы, методика обучения в группах начальной подготовки: Учебное пособие, / А.А. Шерстюк. - Омск, 1991. - 60 с.

8. Федеральный закон РФ «О дополнительном образовании» от 12.07.2001 (принят Постановлением ГД ФС РФ от 12.07.2001 №1794-ІІІ ГД), Статья 13, [Электронный pecypc]. http://www.lawrussia.ru/texts/legal_523.

\title{
Хасабова К.А. \\ Осмысление жизни как личностный аспект самоопределения в раннем юношеском возрасте
}

Южный Федеральный Университет

(Россия, Ростов-на-Дону)

doi: 10.18411/trnio-10-2021-26

\section{Аннотация}

В статье обсуждается проблема психологических предпосылок становления мировоззрения в юношеском возрасте. Рассматриваются возрастные и психологические особенности осмысления жизни как личностного аспекта самоопределения в раннем юношеском возрасте. Анализируются психологические предпосылки формирования мировоззрения личности в юношеском возрасте.

Ключевые слова: юношеский возраст, мировоззрение, когнитивные, социальнокоммуникативные и личностные предпосылки мировоззренческого самоопределения молодого человека, сферы жизнедеятельности молодого человека.

\section{Abstract}

The article discusses the problem of psychological prerequisites for the formation of the worldview in adolescence. Age and psychological peculiarities of the life comprehension as a 
personal aspect of self-determination in early adolescence are considered. The author analyzes psychological preconditions for the formation of a personal world outlook in adolescence.

Keywords: adolescence, world outlook, cognitive, socially communicative and personal preconditions of world outlook self-determination of a young person, spheres of life activity of a young person.

Постановка проблемы. Проблема мировоззренческого самоопределения личности является одной из ключевых в психологии ранней и зрелой юности, ведь именно на этот возрастной период приходится активный поиск молодым человеком целей и смыслов собственного существования, определение своего места в мире, переосмысление стратегических направлений собственной жизнедеятельности, позиционирование себя в системе учебных, трудовых, социальных и др. отношений, решения задач собственного будущего и выстраивание на этой основе дальнейшего жизненного пути. При этом, важным в теоретическом и прикладном аспектах является выделение и систематизация тех психологических предпосылок мировоззренческого самоопределения молодого человека, которые содержательно определяют ход этого сложного динамического процесса.

Этим обусловливается актуальность предлагаемой работы.

Согласно современной периодизации психического развития человека хронологические рамки юношеского возраста обозначены между 15-18 (ранняя юность) и 2025 годами (поздняя юность и переход к взрослости). Этот возраст является завершающим этапом первичной социализации молодого человека, периодом его сознательного самоопределения, приобретения психической (эмоциональной, интеллектуальной) зрелости, формирования нравственного сознания и самосознания. Его успешность, с точки зрения личностного и психического развития, в значительной степени зависит от способности юноши решать основные психологические задачи собственного развития, связанные с ориентированием и определения своего места во взрослом мире, принятием и реализацией новых социальных и гендерных ролей, поиском смысла в выбранной, осваиваемой и выполняемой профессиональной деятельности, формированием готовности к брачносемейным отношениям, дальнейшим совершенствованием внутренней системы ценностных регуляторов поведения и т.д. [7, с.148-149].

Выраженная критичность мышления, появление устойчивой тенденции к обобщенному пониманию мира, к целостной и абсолютной оценки определенных явлений действительности приводит к появлению у молодых людей особого «философского умонастроения», проявляющийся в повышенном интересе к важнейшим проблемам бытия, склонности к теоретизированию, формулировки «глобальных» гипотетических предположений и обобщений, поиска смысла жизни. Этому способствует также и то, что полученные ранее фрагментарные представление составляются теперь в целостную картину мира, содержание которой должно быть обязательно осмысленным юношей с позиций имеющихся у него мировоззренческих убеждений и идеалов.

Таким образом, можно говорить о том, что в юношеском возрасте благодаря увеличению объема знаний, расширению умственного кругозора, появлению теоретических интересов и потребности можно свести все разнообразие конкретных фактов к немногим общим формулам и регуляторным принципам, которые возникают как когнитивные предпосылки становления мировоззрения. В течение юношеского возраста происходит содержательная перестройка взаимоотношений $\mathrm{c}$ окружающими - взрослыми и сверстниками.

По В.И. Слободчикову и Г.А. Цукерман, реальным партнером по событийной общности, с которым отождествляется молодой человек, становится общественный взрослый, воплощенный в системе социальных ролей и частично персонифицированный в таких культурных позициях, как Учитель Мастер Наставник. Взрослый является ценным, прежде всего, своей реальной (а не идеальной - как у подростка) взрослостью, которая содержательно раскрывается, проявляет себя через правила, понятие, принципы, способы 
организации деятельности во всех сферах социально-культурного бытия - в производстве, науке, искусстве, религии, морали, праве и т.д. Именно через приобщение к деятельностным формам взрослости «человек впервые осознает себя потенциальным автором собственной биографии, принимает персональную ответственность за свое будущее, уточняет пределы идентичности внутри совместного бытия с другими людьми» [10, с.43].

Среди тем, на основе которых становится возможным построение такой интерпсихической общности со взрослыми, на первый план выходят проблемы поиска смысла жизни, учебные дела, отношения с окружающими - все то, что связано с самоопределением и самореализацией в субъективно значимых сферах жизнедеятельности. Однако общение со взрослыми на эти темы, по мнению самих юношей и девушек, возможно только на основе диалогичности, равноправия, доверительности и взаимоуважения. Не теряет значимости для юноши и общение со сверстниками, которое характеризуется значительным расширением круга контактов, усложнением их проксемической организацией, углублением и индивидуализацией отношений и сопровождается возникновением устойчивой, дифференцированной, интимной эмоциональной привязанности к значимому другому - дружбы и любви.

В то же время наряду с интенсификацией процессов общения со взрослыми и сверстниками возрастает потребность юноши в так называемом коммуникативном уединении - общении с некоторым идеальным партнером, воображаемым собеседником или собственным «Я», что происходит в форме внутреннего диалога, дневниковой формы и т.д. [17]. При этом содержание и ценностно-смысловые доминанты как межличностного общения, так и уединенной рефлексивной аутокоммуникации касаются одних и тех же, мировоззренческих по своей сути, проблем поиска ответов на экзистенциальные вопросы человеческого бытия-в-мире, раскрытие для себя общих аксиологических, нравственноэтических основ и закономерностей собственной жизнедеятельности, выработки сознательного «Обобщенного, итогового отношение к жизни» (С. Л. Рубинштейн).

Именно в плоскости обсуждения этих проблем и создаются социальнокоммуникативные предпосылки личностного самоопределения лиц юношеского возраста. Не менее существенным для становления мировоззрения является новый уровень развития самосознания молодого человека, его самооценки и образа «Я». Многими авторами отмечается, что присущие этому возрастному периоду существенные сдвиги в сфере самосознания, связанные с открытием собственного «Я», своего внутреннего мира в его целостности и уникальности, формированием личной идентичности, чувством индивидуальной идентичности, преемственности, единства. Изменение самоотношения юноши, осознание им себя как неповторимой личности с собственным строем мыслей, чувств и переживаний, попытки подчеркнуть свою оригинальность, непохожесть на других сочетается с ростом интереса к себе, с мотивационной заряженностью на содержательные оценки различных сторон и качеств собственного «Я», со стремлением к углубленному самопознанию (самонаблюдения, аутокоммуникация, осмысление), критического самоанализа и саморефлексии.

В этом возрасте самооценка, связываясь с жизненными планами, самоутверждением себя как личности, приобретает качественно новый, более дифференцированный и реалистический характер. Тенденция к систематизации и обобщению представлений о собственных физических и психосоциальных качествах, своей самости приводит к относительной стабилизации образа «Я», сбалансированности интегральной совокупности сконструированных ими самопрезентаций (идентичностей, «Я»-позиций и т.д.) [11], гармонизации соотношения между «Я»-Реальное и «Я»-Идеальное, формирование положительной «Я»-концепции, чувство самоуважения и самоценности, более или менее адекватного уровня притязаний, что, в свою очередь, существенно влияет на эмоциональноволевую сферу юноши, в частности, на механизмы внутреннего торможения и способность к выборочному реагированию на внешние воздействия [8]. 
Говоря о психологических предпосылках становления мировоззрения лиц юношеского возраста, следует отдельно отметить содержание и формально-динамические особенности их ценностных отношений. С точки зрения содержания ценностные ориентации молодого прежде всего касаются 1) отношение к собственной телесности (здоровье как ценность) и собственного Я (ценности самопознания и самореализации) 2) отношение к другим (широкий круг институциональных, профессиональных, групповых и др. ценностей, связанных с межличностными коммуникациями и интеракции) 3) отношение к вещам и явлениям окружающего мира (материальные, познавательные и др. ценности) 4) отношение к Абсолютному, что выражается в так называемых высоких духовных («вечных») ценностях.

Формально динамический аспект очерченных ценностных отношений раскрывается в образе их упорядочения юношей в вертикально (иерархически) и горизонтально организованной аксиологической структуре, а также о том, как они способны побудить личность к соответствующему действию, поступку.

Следует также добавить, что самоопределение считается одним из основных личностных новообразований юношеского возраста $[7 ; 9 ; 14 ; 15]$, которое связано с активным формированием собственной позиции относительно системы культурных ценностей «с целью определения и обоснования для себя ценностно-смысловых основ собственной жизненной концепции, а также выбора способов и форм ее реализации» [18, c.93]. Источником такого самоопределения выступает потребность человека в формировании смысловой системы, в которой слиты представления о мире и самом себе, а также имманентное сознательное стремление к поиску и реализации смысла собственного существования в конкретных культурно-исторических условиях [16].

При этом подчеркивается, что процесс самоопределения разворачивается в двух плоскостях - ценностно-смысловой и временной. Первая представлена системами индивидуальных ценностей и смыслов; вторая - взаимосвязанными «пространствами» психологического прошлого, настоящего и будущего, в пределах которых реализуются (актуально или потенциально) указанные аксиологические системы. При этом отмечается, что существенной особенностью личностного самоопределения является его ориентированность в будущее, функциями которого является «обеспечение смысловой и временной перспективы личности» [1, с.49].

Кроме этого, психологический механизм самоопределения личности описывается через сложное динамическое взаимодействие процессов идентификации и индивидуализации, опосредующих конструирование субъектом собственной идентичности [6]. В связи с этим можно предположить, что идентификационные процессы во многом определяют содержание мифологических мировоззренческих структур личности, которые, играют ведущую роль в возникновении у юноши ощущения собственной принадлежности к определенным социальным сообществам.

Итак, через решение жизненно важных проблем («Для чего я живу?», «Как жить?», «Каким быть?», «В чем моя уникальность?», «Что для меня является ценным в жизни?», «Как мне достичь этого, воплотить в жизнь?» и т.п.), осознание и осмысление собственной жизни, самопознание и самоопределение молодой человек осуществляет мировоззренческий поиск, формирует свою мировоззренческую культуру, производя собственные жизненные позиции и принципы, выстраивая систему собственных взглядов на мир и на свое место в нем, направляя свою активность в соответствии со своими мировоззренческими идеями и принципами.

Перспективы дальнейших исследований в данном направлении видим в раскрытии психологических механизмов генерализации и структуризации юношей своих представлений 
о закономерностях и характеристик мира, общества, человеческой жизни в целом, их трансформации в мировоззренческие убеждения, идеалы и принципы.

$$
* * *
$$

1. Гинзбург М.Р. Психологическое содержание личностного самоопределения / М.Р. Гинзбург // Вопросы психологии. - 1994. - №3. - С.43-53.

2. Кон И.С. Психология ранней юности: Кн. для учителя / И.С. Кон. - М.: Просвещение, 1989. - 255 с.

3. Кулагина И.Ю. Возрастная психология: Полный жизненный цикл развития человека: Учеб. пособие для студ. высш. учеб. заведенный / Ю.И. Кулагина, В. Н. Колюцкий. - М.: ТЦ «Сфера», 2001. - 464 с.

4. Леонтьев Д.А. Выбор как деятельность: личностные детерминанты и возможности формирования / Д.А. Леонтьев, Н.В. Пилипко // Вопросы психологии. - 1995. - №1. - С.97-110.

5. Мировоззренческая культура личности: философские проблемы формирования. - К.: Наукова думка, 1986. 294 с.

6. Овчинникова Ю.Г. личностная идентичность: от философских истоков к психологической сущности / Ю.Г. Овчинникова, П.Б. Селюгина // Психология. Журнал Высшей школы экономики. - 2012. - Т.9. - №1. - С.153161.

7. Ремшмидт X. Подростковый и юношеский возраст. проблемы становления личности / Х. Ремшмидт. - М.: Мир, 1994. - 320 с.

8. Сапогова Е.Е. Психология развития человека. Учебное пособие / Е.Е. Сапогова. - М.: Аспект Пресс, 2005. $460 \mathrm{c}$.

9. Сафин В.Ф. Психология самоопределения личности / В.Ф. Сафин. - Свердловск: Свердловский педагогический институт, 1986. - 146 с.

10. Слободчиков В.И. Интегральная периодизация общего психического развития / В.И. Слободчиков, Г.А. Цукерман // Вопросы психологии. - 1996. - №5. - С.38-50.

11. Титов И. Некоторые аспекты образа ә и идентичности современных юношей / И.Г. Титов // Актуальные проблемы психологии: Сборник научных трудов Института психологии имени Г.С. Костюка АПН Украины. - Киев; Нежин ЧП Лысенко, 2015 - Том ХИ. - Психология личности. Психологическая помощь личности. Вып. 15. - С.531-538.

12. Титов И. Особенности смысловой структуры мировоззрения человек юношеского возраста / И. Титов // Психология и личность. - 2017. - №2 (12). - С.168-184.

13. Титов И. Жизнедеятельностные контексты личностного самоопределения в юношеском возрасте / И. Титов // Вестник Херсонского государственного университета. Серия «Психологические науки». - 2015 - Выпуск 1. - Т. 2. - С.39-45.

14. Фельдштейн Д.И. Психология взросления: структурно содержательные характеристики процесса развития личности: избранные труды / Д.И. Фельдштейн. - М.: МПСИ, 2004. - 672 с.

15. Формирование личности в переходный период от подросткового к юношескому возрасту / Под ред. И.В. Дубровиной. - М.: Педагогика, 1987. - 478 с.

16. Чудновский В.Э. Смысл жизни и судьба / В.Э. Чудновский. - М.: Ось-89, 1998. - 236 с.

17. Шаповаленко И.В. Возрастная психология (Психология развития и возрастная психология) / И.В. Шаповаленко. - М.: Гардарики, 2005. - 349 с.

18. Шибаева М.М. Самоопределение личности в культуре как мировоззренческая проблема / Н.Н. Шибаева // Культура и мировоззрение. Вып. 11. Материалы Всесоюзной научно-практической конференции «Формирование научного мировоззрения - основа коммунистического воспитания». - М., 1985. - С.93-97.

19. Щедровицкий П.Г. Очерки по философии образования / П. Щедровицкий. - М.: Эксперимент, 1993. - 154 с.

\section{Чаплыгин С.С., Ровнов С.В., Мазанкина Е.В., Беляев П.А. Психофизиологическое состояние индивида в процессе обучения с использованием технологии VR} ФГБОУ ВО СамГМУ Минздрава России (Россия, Самара)

doi: 10.18411/trnio-10-2021-27

Аннотация

Технологизация обучения продолжает оставаться актуальным вопросом, который в свою очередь порождает новые проблемы связанные с процессом индивидуализации обучающего процесса. В статье рассмотрены результаты исследования применения технологий VR в обучающем процессе, выявления взаимосвязи между поведением в виртуальной реальности и психофизиологическим состоянием индивидов.

Ключевые слова: психофизиологические состояния, виртуальная реальность, VRтехнологии, обучение. 